\title{
Market Effects of Voluntary Climate Action by Firms: Evidence from the Chicago Climate Exchange
}

\begin{abstract}
Why do for-profit firms take voluntary steps to improve the environment? Do green actions indicate that managers are wasting resources in costly programs to produce benefit that cannot be captured by the firm? Or is voluntary environmental spending profitable for a business sense? Empirical evidence is decidedly mixed. In this study, we use 19 years of monthly stock price returns to examine the profitability of participation in the world's largest voluntary greenhouse gas mitigation program: the Chicago Climate Exchange (CCX). After controlling for systemic market risk as well as industry-specific shocks, we find statistically significantly positive excess returns for firms that announce their decision to join CCX. In addition, the progress of proposed greenhouse gas legislation (the Waxman-Markey bill) had a positive and large impact on excess returns for CCX member firms, suggesting that a major incentive for firms to join CCX may be to prepare for future regulation. Marginal abatement costs (proxied by the carbon price), on the other hand, were unrelated to excess returns. Our results imply that voluntary approaches should play a role in combating climate change, but that relying on them alone is not enough.
\end{abstract}




\section{Introduction}

Environmental regulation is usually discussed in the context of a tradeoff between firm profits and environmental benefits. In contrast, voluntary environmental action is sometimes presented as a win-win situation, where everybody benefits, provided that firm profits increase and the environmental action is effective. There is an ongoing debate about whether such a virtuous cycle of profitability and environmental responsibility exists; if so, voluntary approaches could be used to relax or replace regulation, providing firms with the maximum amount of flexibility (Alberini and Segerson, 2002; Khanna, 2001).

US Climate policy is a particularly important example of whether voluntary approaches can obviate regulation. At the time of this writing, the USA does not regulate greenhouse gas (GHG) emissions on a national level but instead relies on voluntary firm action. ${ }^{1}$ In contrast, most other industrialized nations have chosen to introduce binding regulation.

There are theoretical arguments both in favor and against the profitability of voluntary environmental investment, and a growing empirical literature that examines the relationship between environmental and financial performance. Our paper contributes to this literature by studying the effect of membership in the Chicago Climate Exchange (CCX), the largest voluntary GHG cap-and-trade market to date.

CCX was established in 2003 to provide a formal market for firms to voluntarily, but verifiably, reduce GHG emissions, and it expired at the end of 2010. Unlike other

\footnotetext{
1 Although the EPA changed its policy and now includes $\mathrm{CO}_{2}$ as an air pollutant, there are no federal standards, taxes or other regulation that puts a price on $\mathrm{CO}_{2}$ emissions. Regional and local initiatives exist, however, such as the Regional Greenhouse Gas Initiative (RGGI) and California's Global Warming Solutions Act (AB 32).
} 
voluntary GHG programs, CCX included both strict provisions and standards for the auditing of emissions reductions, and a formal market for the purchase of abatement credits. In that sense, CCX was a close voluntary equivalent to a mandatory carbon market, the policy instrument of choice in many countries to reduce GHG emissions of industry. To our knowledge, this is the first attempt to examine the effect of CCX membership on firm financial performance. Our findings therefore have an immediate relevance for environmental regulation and policy.

The empirical literature about the profitability of voluntary environmental spending can be separated into two broad groups. The first compares financial performance of a “green” portfolio with that of other portfolios over time, usually based on some environmental performance index. ${ }^{2}$ The main challenges with this method are unobserved heterogeneity (Telle, 2006) and the identification of the effect of voluntary action. Even if an unbiased estimator of the effect is found, the direction of causation cannot always be resolved: Are green firms more profitable because they are green, or are they green because they can afford to be?

The second thread of literature measures the effect of a discrete event in time (e.g. the discharge of toxic waste) on firm profits. ${ }^{3}$ Studies of this type offer an advantage in identification and causation inference relative to the long-term comparison of portfolios, but suffer from the limitation that only environmental performance that is "time stamped" can be investigated.

Our approach is based on a difference-in-difference estimation over time that

\footnotetext{
2 E. g., Derwall et al. (2005); Dowell et al. (2000); Hart and Ahuja (1996); King and Lenox (2001); Russo and Fouts (1997); Yamashita et al. (1999); Ziegler et al. (2007).

3 E. g. Dasgupta et al. (2001); Filbeck and Gorman (2004); Fisher-Vanden and Thorburn (1998); Gupta and Goldar (2005); Khanna et al. (1998); Konar and Cohen (1997, 2001); Muoghalu et al. (1995).
} 
includes discrete events, thus combining the two approaches. Our primary focus is on estimating the effect of discrete events on firm profits, such as announcements to join CCX and political information relevant for this market. In particular, we argue that the passage of the 'Waxman-Markey' bill in the US House of Representatives raised the likelihood of a mandatory cap-and-trade system in the short to medium term. We use additional data to control for market performance, such as excess returns from industry rivals and the CCX carbon price (as a proxy for marginal abatement costs implied by CCX membership). To control for self-selection bias into the voluntary program, we construct control groups of nonmember firms based on propensity score matching.

We find positive and statistically significant excess returns after firms announce their decision to join CCX. Likewise, the passing of the Waxman- Markey climate bill led to positive and statistically significant excess returns for $\mathrm{CCX}$ member firms relative to nonmember firms, implying that firms who had gained experience in the voluntary market were believed to be better prepared for a possible mandatory market (the mandatory market has in fact not materialized to date). The positive excess returns from the climate bill are about twice the magnitude of the announcement effect, suggesting that preparing for future mandatory regulation was an important motivation for firms to join CCX.

\section{Background and Literature Review}

At the time of the Kyoto Protocol under the United Nations Framework Convention on Climate Change, the USA was the largest greenhouse gas emitter in the world, and therefore the most prominent non-participant. While that process ultimately resulted in a market for tradable carbon offsets in Europe (the EU Emissions Trading Scheme), the 
lack of an agreement or legislation in the US meant that emission of greenhouse gases remained unregulated. In 2003, the Chicago Climate Exchange opened a trading exchange for voluntary greenhouse gas emissions reductions and offsets in North America and Brazil. CCX has been followed by a host of nonprofit and for-profit companies that seek to generate, finance, sell, and market emissions reductions and offsets. $^{4}$

\subsection{The Chicago Climate Exchange (CCX)}

The CCX was a voluntary GHG cap-and-trade market that existed from 2003 to 2010, and was the most significant voluntary GHG market to date. Member firms paid an annual membership fee and agreed to reduce their emissions of greenhouse gases. The fee ranged from $\$ 1,000$ to $\$ 35,000$ per year, depending on the size of the firm and the type of membership. Although participation was voluntary, compliance with emission reduction objectives was legally-binding for members.

All emission baselines and annual emission reports were subject to independent verification. ${ }^{5}$ Members committed to reduce their emissions by a fixed amount below their established baseline, which included about 700 million tons of $\mathrm{CO}_{2}$ (corresponding to about a third of the EU ETS baseline, the largest cap-and-trade market to date). Firms that reduced beyond their target received surplus allowances to sell or bank; those who failed to meet the targets complied by purchasing emissions allowances. These

\footnotetext{
${ }^{4}$ A review of the CCX and other voluntary programs can be found in Kollmuss et al. (2008).

5 There are 3 classes of membership on CCX: Members, participant members, and associate members. Participant members establish a registry and get their emissions verified, but don't make any commitment on emissions reduction. Associate members have negligible direct emissions, but pledge to report and fully offset their indirect emissions. We focus here solely on full members: Those with sizeable direct emissions who pledge to reduce them.
} 
allowances, or 'Carbon Financial Instrument’ (CFI) contracts, consisted of exchanged allowances and carbon offset credits from qualifying projects, which could be located in any country except those listed in Annex 1 of the Kyoto protocol. Figure 1 shows the CCX carbon price and trade volumes.

There were two distinct phases to the CCX program. During phase 1, from 2003 to 2006, members agreed to cut their emissions by $1 \%$ each year below their baseline average (1998 to 2001), thereby achieving a reduction of $4 \%$ by the end of the fourth year. During phase 2, from 2007 to 2010, existing members had to further cut their annual emissions to achieve the target of $6 \%$ by 2010 . New members who did not participate in the first phase therefore had to reduce emissions by $1.5 \%$ per year such that they achieved the same relative emissions reduction as phase 1 members. At the end of 2010, the capand-trade market was discontinued. ${ }^{6}$

Figure 1 about here.

\subsection{Related literature}

The literature about voluntary environmental investment revolves around the question of whether such investments are beneficial for firms, shareholders and/or the environment. Proposed answers range from a flat-out rejection of voluntary environmental investments as an irresponsible waste of money (Friedman, 1970) to a

\footnotetext{
${ }^{6}$ CCX was founded by Climate Exchange PLC, a publicly traded company. In July 2010, Intercontinental Exchange (ICE) acquired CCX and its global affiliates. Members reduced emissions by more than the required amount by the end of 2010, explaining the virtually zero carbon price in the last year. In July 2011, ICE launched the CCX Offset Registry Program, a platform to generate, register and trade carbon credits based on verified emission reductions (CCX fact sheet by ICE, available at www.theice.com/cCX, last accessed in June 2012).
} 
belief that such investment not only pay for itself, but will generate a profit in most cases, while improving environmental quality at the same time (Porter and van der Linde, 1995). A general discussion about when corporate social responsibility pays off can be found in Heal (2005) and Khanna (2001).

Arora and Gangopadhyay (1995) develop a model in which some firms find it profitable to over-comply with environmental regulation. Consumers have identical green preferences but varying income levels, leading to market segmentation based on willingness and ability to pay. An important assumption in the model is that firms are able to effectively and credibly communicate the "greenness" embedded in their product, a point also emphasized by Reinhardt (1999). More generally, voluntary green spending can be viewed as a form of advertising or marketing, allowing the firm to gain market share when consumers value environmental quality. Anton et al. (2004) find that consumer pressure is an important factor in explaining voluntary environmental investment by firms.

A second rationale for voluntary environmental improvement comes from the investor side. Heinkel et al. (2001) construct a model where a subset of investors have green preferences and refuse to hold stock from "dirty" firms. If the pool of green investors is large enough, equity from green firms will sell at a premium, leading to lower capital costs for these firms relative to the market overall.

Voluntary action could also be explained by strategic interaction between firms. Nehrt (1996) examines timing and intensity of environmental investment, and finds that first movers profit more than followers. This result is closely related to the literature about "raising rivals' costs", where a dominant firms seeks to gain market share at the 
expense of its rivals by increasing (everyone’s) costs (Hart and Tirole, 1990;

Krattenmaker and Salop, 1986; Salop and Scheffman, 1983, 1987). The cost increase can take many forms, including triggering new standards by over-complying with current regulation. The strategy is profitable if the dominant firm's average cost increase is less than the marginal cost increase of its rivals.

There may be further scope for strategic voluntary action if long-term firm profits also depend on their relationship with stakeholders such as workers, labor unions, municipalities, as well as different levels of government. Even though voluntary action may be costly in the short run, improved relations may more than recover the costs in the long-run (Barnett and Salomon, 2006; McWilliams et al., 2006). Naturally, this depends on the magnitude of the involved short-run costs and the long-run benefits, as well as investors’ rate of time preference.

Lastly, another potential benefit of voluntary emission reductions, and one that turns out to be pertinent for our case, is the experience gained in abatement, which may make it less costly to comply if regulation is later imposed (Khanna, 2001). Our results suggest that this pathway could play an important role for participation in CCX.

The common underlying idea of these theoretical arguments is that the benefits from voluntary action may outweigh the costs, rendering voluntary action profitable for firms and shareholders, not just the environment. ${ }^{7}$ This is the theoretical starting point for empirical studies aiming to identify a link between voluntary environmental action and financial performance.

\footnotetext{
7 There is a separate literature that focuses specifically on the environmental effectiveness of various voluntary programs. In the current context, Matisoff (2012) finds that emissions from firms that participated in the CCX decreased, but that this decrease was due to a reduction in output rather than a reduction of carbon intensity.
} 
Many applications have focused on local pollutants such as toxic waste. The results are mixed; some papers find a positive relationship between environmental and financial performance (Dowell et al., 2000; Hart and Ahuja, 1996; Khanna et al., 1998; King and Lenox, 2002; Konar and Cohen, 2001; Muoghalu et al., 1995; Russo and Fouts, 1997), whereas others find a negative relationship (Konar and Cohen, 1997) or no correlation at all (Filbeck and Gorman, 2004; King and Lenox, 2001; Telle, 2006).

Our paper measures the financial performance of a voluntary GHG reduction program. Voluntary emission reduction of a global stock pollutant is different to reducing local pollution in several important ways. On the one hand, GHG emissions of any single firm are unlikely to yield a visible environmental impact. This means that consumers and investors have to be informed about the existence and effects of climate change in order to have a preference for products or shares of the GHG-reducing firm visà-vis their competitors. On the other hand, the global nature of GHG emissions can potentially send positive signals far beyond a local region. For example, Japanese consumers may value a reduction of GHG emissions by a US firm as much as Americans, which is presumably not the case for a reduction in local pollution. Many of the CCX members are multinational firms whose shares are globally traded.

Few papers have focused on the effect of GHG-reducing programs on firms' financial performance. Kim and Lyon (2011) provide evidence that firms strategically disclose emissions in the US Department of Energy's 1605b Program, using a propensity score matching technique to match participants with rivals that is very similar to the one we use in our paper. They find that firms tend to report emission reductions but withhold emission increases, and that participant firms' emissions actually increased relative to 
non-participating industry rivals. Mallory (2009) examines a similar program in Canada with a focus on firms' market performance, but finds no statistically significant difference relative to firms that do not disclose emissions.

Oberndorfer (2009) examines excess returns of EU electricity generators and finds that they are positively related to the permit price in the EU Emissions Trading Scheme after controlling for market risk (since the EU ETS is a mandatory market that covers a particular set of industries, there are no non-participating industry rivals). The results could be explained by a combination of cost pass-through to consumers and a very generous free allocation policy (Hintermann, 2011; Sijm et al., 2006). ${ }^{8}$

The two papers that are perhaps closest to ours are Fisher-Vanden and Thorburn (1998) and Ziegler et al. (2009). The former is an event study among US firms that joined the voluntary programs Climate Leaders and Ceres, both of which aim to reduce GHG emissions. Matching daily stock data with firm announcements to join either program, the authors find that announcement excess returns were negative. The results varied somewhat by industry as well as by the book-to-market ratio, but they conclude that for the firms in their sample, voluntary environmental action was not profitable.

Ziegler et al. (2009) compare the average stock performance of portfolios of US and European stock that differ in their climate-related policies, using the same four-factor model that is on which we base our analysis. Environmental action taken by firms, such as announcing emission-reduction goals, or press releases relating to climate change, were seen to reduce average returns over the sample period (2001-2006) for the US firms.

\footnotetext{
${ }^{8}$ Furthermore, it is possible that the EUA carbon price during the first part of phase 1 substantially exceeded marginal abatement costs (Hintermann, 2010), and that the price was driven by the (declining) probability that the cap would turn out to be binding at all (Hintermann, 2012) .
} 
For European firms, they measured a positive effect on returns for the period after 2003, when the EU adopted a more forceful approach to combating climate change. Our paper provides additional empirical evidence about the effect of voluntary reductions of GHG emissions on firms' financial performance in the absence of mandatory regulation, but where such regulation is at least possible in the short to medium term.

\section{Model}

Our goal is to identify the effect of joining CCX on firm profitability, which we proxy by excess returns. ${ }^{9}$ We start with the Capital Asset Pricing Model (CAPM) developed by Sharpe (1964) and Lintner (1965), ${ }^{10}$ and extend it by including relevant firm-level data. Our identification strategy is a difference-in-difference estimation, where the treatment group consists of firms that joined CCX. Since membership is endogenous, we construct the control group through propensity score matching. Finally, we use the panel nature of our data to control for unobserved heterogeneity across firms.

\subsection{The four-factor model}

According to the CAPM, risk-adjusted excess returns from holding a particular security

\footnotetext{
${ }^{9}$ If the market correctly prices securities, stock prices are equal to the discounted expected stream of dividends, which in turn reflect firm profits. If the efficient market hypothesis does not hold and stock prices are also affected by variables other than future profits, such as self-fulfilling expectations or investor "herding" behavior, our approach remains valid as long as the deviation between price and fundamental equally applies to CCX member firms and their rivals. Other researchers use Tobin's Q (equity value divided by market replacement cost of assets) which can be interpreted as a measure of intangible firm value. But like stock prices, Tobin's $Q$ tends to be non- stationary, which complicates statistical inference in our multivariate regression approach. Taking first differences solves the nonstationarity problem, but since the market replacement cost presumably does not change month-to-month, the information contained in first-differenced Tobin's $Q$ is identical to the information contained in returns (proportional first differences).

${ }^{10}$ See Fama and French (2004) for a review of its history and application. The main reason why we use the CAPM is that it is frequently applied finance, and its parsimonious nature. Rather than making stock prices depend on a range of (usually unobserved) firm characteristics, the CAPM relies on aggregate market information to price stock.
} 
are equal to overall market returns, or:

$$
\frac{E\left[r_{i}\right]-r_{f}}{\beta}=E\left[r_{m}\right]-r_{f} \quad \text { with } \quad \beta \equiv \frac{\operatorname{Cov}\left[r_{i}, r_{m}\right]}{\operatorname{Var}\left[r_{m}\right]}
$$

where $E\left[r_{i}\right]$ is the expected return on asset $i$ (which can be a portfolio or an individual security $\left.{ }^{11}\right), r_{f}$ is the risk-free rate of interest, and $E\left[r_{m}\right]$ refers to the expected rate of return of the stock market as a whole. The difference between the return from a risky asset and the risk-free rate of interest is known as the excess return or the risk premium.

The adjustment factor $\beta$ in equation (1) relates expected excess returns from holding an individual security to expected excess returns in the market overall. It measures market or systemic risk, which is the risk that cannot be diversified away by combining securities into one portfolio. In the original CAPM, $\beta$ is the sole variable (also called "factor") that determines the average return of an asset, the underlying assumption being that markets are efficient and all relevant other information is already incorporated in prices. Because of this, the CAPM is also known as the "1-factor model" and usually expressed by restating (1) in terms of excess returns: $E\left[r_{i}\right]-r_{f}=\beta\left(E\left[r_{m}\right]-r_{f}\right)$. The associated empirical regression equation is derived by adding a time dimension, a constant, and replacing the expectations with an error term:

$$
r_{i t}-r_{f t}=\alpha+\beta\left(r_{m t}-r_{f t}\right)+\epsilon_{i t} \quad \text { with } \quad E\left[\epsilon_{i t}\right]=0 ; \operatorname{Var}\left[\epsilon_{i t}\right]=\sigma^{2}
$$

\footnotetext{
${ }^{11}$ For a balanced panel with $\mathrm{N}$ x T observations, regressing individual stock returns on time-varying common factors yields the same point estimates as regressing cross-section averages (i.e. portfolio returns) on the same factors. In our case of an unbalanced panel, the point estimates will slightly differ because the portfolio approach equally weights time averages, whereas the individual stock regression gives equal weight to all observations, implying a greater weight for months with more data. The interpretation of $\alpha$ and $\beta$ remains unchanged.
} 
The constant $\alpha$ is known as Jensen's alpha. Since a nonzero value for $\alpha$ indicates an over- or undervaluation of an asset, which should be arbitraged away if transactions costs are not too high, the null hypothesis is always that $\alpha=0$. The adjustment factor is unity for the market overall by construction. If asset $i$ is associated with a higher systemic risk than the market overall, $\beta>0$, and vice versa.

To address some of the anomalies observed in stock markets, ${ }^{12}$ Fama and French (1992, 1993) extended the 1-factor model to adjust for price effects related to firm size and value. Carhart (1997) added a fourth factor in order to address momentum trading strategies, leading to the following specification, which has become known as the "fourfactor" model in the financial literature:

$$
r_{i t}-r_{f t}=\alpha+\beta_{1}\left(r_{m t}-r_{f t}\right)+\beta_{2} S M B_{t}+\beta_{3} H M L_{t}+\beta_{4} M O M_{t}+\epsilon_{i t}
$$

The factor $S M B_{t}$ ("small-minus-large") is computed as the difference between the return of a stock portfolio comprising small firms (in terms of market value) and that of a portfolio of large firms. $H M L_{t}$ ("high-minus-low") refers to the valuation of a stock relative to company assets and is the return of a portfolio of stocks with a high book-tomarket ratio (so-called "growth" stocks) minus a portfolio of stock where book-to-market is low ("blue chips"). ${ }^{13}$ Finally, $M O M_{t}$ is the "momentum factor" and is the difference between the return of a portfolio comprised of "winning" stocks minus the return of a

\footnotetext{
${ }^{12}$ See e.g. Banz (1981) and De Bondt and Thaler (1985).

${ }^{13}$ The book-to-market ratio is defined as book equity divided by market equity. Book equity captures a firm's total assets minus liabilities and is defined as the value of stockholders' equity plus the value of deferred taxes and investment tax credit, minus the value of preferred stock; market equity is the stock price times the number of shares.
} 
portfolio of "losing" stock. ${ }^{14}$ Data for $S M B_{\mathrm{t}}, H M L_{\mathrm{t}}$ and $M O M_{\mathrm{t}}$ for the US stock market are available from Kenneth French's online data library. ${ }^{15}$ The four-factor model is a frequently used asset-pricing model in applied work, mainly due to its parsimony and data requirements. Besides the three factors and the risk-free rate of interest, all of which are publicly available, the only additional data needed are firm returns. In general, nonsystemic or idiosyncratic asset risk can be diversified away by including a sufficient number of imperfectly correlated assets into a single portfolio and is thus not reflected in average security prices according to equations (2) and (3). However, since we aim to identify the effect CCX membership on individual firm profits, we need to extend the four-factor model to include firm-level information.

\subsection{Adding firm-level information}

First, we include a dummy that marks CCX membership. Since the market incorporates information as soon as it becomes available (whether it does so fully and/or immediately is a matter of some dispute in the empirical literature), we use firm announcements to join CCX rather than the actual joining dates. The membership dummy reverts to zero for firms that exit the system at the end of Phase I. We do not observe any member firm exits in Phase 2.

The second variable we include is a regulatory expectations proxy. The likelihood of future regulation is one of the possible reasons for joining a voluntary emissions reduction program such as CCX. Specifically, we focus our attention on the Waxman-

\footnotetext{
14 The actual calculation is the difference between the average of 2 two winning portfolios (formed from small firms and big firms), minus the average from two losers (small and big). The winners and losers are formed above the $70 \%$ percentile form the previous month, and below the $30 \%$ percentile, respectively.

${ }^{15}$ http://mba.tuck.dartmouth.edu/pages/faculty/ken.french/data library.html (last access on 8/16/2011).
} 
Markey bill (the 'American Clean Energy and Security Act'), which sought to limit the emission of greenhouse gases and establish a mandatory emissions-trading scheme at the Federal level. Our hypothesis is that passage of the bill by the House of Representatives increased investors' assessment of the probability that a mandatory federal cap-and-trade system would be instituted in the medium term. In such a system, previous CCX membership could be viewed as an advantage because these firms already have market experience. ${ }^{16}$ We add a time dummy for June 2009, the month when the WaxmanMarkey bill was passed in the US House of Representatives, as well as an interaction term between membership and the Waxman dummies to get a difference-in-differencetype estimator.

Third, we incorporate information about the compliance costs implied by CCX membership (abatement costs plus net permit expenditures). We proxy these costs with the CCX carbon price, which should be a lower bound for marginal abatement costs. ${ }^{17} \mathrm{~A}$ price change will translate to a change in overall expected compliance costs, which in turn implies lower profitability and thus lower excess returns, ceteris paribus.

Next, we control for industry-level shocks by including average excess returns of 4digit industry rivals. That is, we compute monthly average returns by 4-digit SIC code

\footnotetext{
${ }^{16}$ Prospects for an imminent federal cap-and-trade system decreased somewhat when the bill was tabled in the Senate and attention was focused on the recession and the deficit. This undoubtedly postponed the advent of a mandatory program, but mandatory permit trading remains the cornerstone of action against climate change in most other OECD countries, making it at least possible that the US will eventually institute a Federal mandatory system as well. Because there was no clearly identifiable moment at which the probability of a mandated program decreased, we did not include an "anti-Waxman" dummy in the analysis. If such a moment existed, we would expect negative excess returns for CCX members. ${ }^{17}$ The weak inequality follows directly from stepwise marginal abatement cost curves. A second reason for our assumption is related to perception: The voluntary nature of the market should not change the basic arbitrage condition that firms abate as long as this is cheaper than buying permits. The reverse, however, may not be true if firms' main incentive to join CCX is to generate an image of greenness: They could choose to abate even if this is costlier than covering all of their emissions by purchasing permits. There remains a stigma of absolution from environmental sins associated with buying offsets, if not among economists then in the general public.
} 
and add them as an additional variable to each firm, based on its industry classification.

Finally, we further control for firm-specific unobserved heterogeneity by allowing for random effects (RE).

\subsection{Econometric specification}

In order to derive an econometric specification that is consistent with theory, we have to start by the price-level equation that gives rise to the CAPM, add the new variables in a consistent way and then derive the regression equation based on returns. These steps are carried out in Appendix A. The resulting econometric specification is

$$
\begin{aligned}
& r_{i t}-r_{f t}=\alpha+\beta_{1}\left(r_{m t}-r_{f t}\right)+\beta_{2} S M B_{t}+\beta_{3} H M L_{t}+\beta_{4} M O M_{t} \\
&+\gamma_{1} \Delta M_{i t}+\gamma_{2} \Delta W_{t}+\gamma_{3} M_{i t-1} \Delta W_{t} \\
&+\delta_{1}\left(r_{i t}^{s i c}-r_{f t}\right)+\delta_{2} r_{t}^{C}+\delta_{3}\left(M_{i t-1} r_{t}^{C}+\Delta M_{i t} l n P_{t-1}^{C}\right)+\epsilon_{i t}+u_{i} \\
& E\left[\epsilon_{i t}\right]=E\left[u_{i}\right]=0 ; \quad \operatorname{Var}\left[\epsilon_{i t}\right]=\sigma_{\epsilon} ; \quad \operatorname{Var}\left[u_{i}\right]=\sigma_{u}
\end{aligned}
$$

The first line represents the four-factor model. On the second line, $M_{i t}$ is the membership dummy and is equal to 1 for active CCX members (more precisely, for firms that have announced that they would join), and zero otherwise. Therefore, the firstdifferenced membership dummy $\Delta M_{i t}$ is equal to one during the month of the announcement, minus one when a firm leaves the system, and zero otherwise. ${ }^{18}$ We refer

\footnotetext{
18 We set the announcement dummy to one for the month of the announcement for all firms. To address the fact that some firms joined late in the month, giving the market much less time to react than for firms joining early, we set the announcement dummy equal to one for the month following the announcement month for all firms that announced their decision to join after the $15^{\text {th }}$ of each month. This means that the period during which we measure excess returns after the announcement varies from a minimum of 15 days (for firms announcing on the $15^{\text {th }}$ ) to a maximum of 44 days (for firms announcing on the $16^{\text {th }}$ ).
} 
to the first-differenced membership dummy as the "announcement” dummy. ${ }^{19} W_{t}$ is a time dummy that takes the value of 1 in June 2009 (the passing of the Waxman-Markey bill), and zero for all other months. The coefficient on the interaction term with the membership dummy $\left(\gamma_{3}\right)$ captures the difference-in-difference effect of the bill on the treated, i.e. on member firms.

The third line in (4) contains excess returns from industry rivals $\left(r_{i, t}^{s i c}\right)$, carbon price returns $\left(r_{t}^{C}\right)$, carbon price levels $\left(P_{t}^{C}\right)$, as well as an interaction term between carbon prices and CCX membership. The effect of carbon price returns on returns for nonmembers is captured by $\delta_{2}$ and is presumably zero, since these firms do not face a binding carbon constraint. For member firms, the effect of carbon prices is given by $\delta_{2}+\delta_{3}$, such that $\delta_{3}$ is the difference-in-difference estimator for the effect of carbon prices on the treatment group. The first term in the parenthesis is the effect of carbon price returns for “old” member firms, i.e. those that announced their decision to join at least one month prior to time $t$, whereas the second term is the effect of carbon prices levels on firms that make their announcement in that month. The two effects differ in their specification because for “old” members, a (proportional) change in carbon prices leads to an adjustment of the expected abatement costs that were priced in previously, whereas for new members, carbon prices are incorporated into expected future profits for the first time. Finally, $\epsilon_{i l}$ and $u_{i}$ are the idiosyncratic error and the firm-specific error term (the random effect), respectively. We estimate (4) using monthly data from 1991 to 2009.

\footnotetext{
${ }^{19}$ In specification (4), the effect of joining CCX is captured by a one-time effect on returns, which is equivalent to a permanent effect on prices. To control for the possibility of lagged and/or permanent effect on returns, we introduced lagged versions of the announcement dummy, but they were statistically insignificant (results available on request).
} 


\subsection{Matching}

A major concern in estimating our model is self-selection. Treatment and control group membership is not randomly assigned but chosen by firms, which could lead to seriously biased coefficient estimates.

To address this problem, we construct the control group using propensity score matching. Specifically, we match CCX member firms for the period between 1990 and the creation of the CCX (April of 2003). We estimate the propensity to join using the market value of the firm, the returns from holding firm stock, and the volume of shares traded (along with squared terms for each of those variables). We match members firms to their 5 nearest neighbors, and to their nearest neighbor (without replacement). ${ }^{20}$ We perform the matching procedure on two samples: across all industry rivals (firms that share the two-digit SIC code with a CCX member firm) and within industry (matching firms within particular 2-digit SIC code).

\section{Data and Results}

Our data consists of monthly stock prices taken from the Center for Research in Security Prices (CRSP) for the years 1991 - 2009. ${ }^{21}$ We calculate our dependent variable, monthly excess return, by subtracting the risk-free rate of interest (RF) from monthly

\footnotetext{
${ }^{20}$ As in Kim and Lyon (2011), the voluntary program can be viewed as a treatment, and here the effect of joining CCX is treatment effect on the treated. Complicating the analysis is the fact that different firms joined at different times. In theory, the average treatment effect on the treated (ATT) would have to be constructed from several distinct effects occurring at different times. Rather than explicitly computing the ATT for each firm and then form an average, we construct a single control group by matching and use a Din-D-type estimation procedure.

${ }^{21}$ The CRSP is a database of daily and monthly stock prices for publicly-listed firms in the United States going back to 1925. CRSP is maintained at the University of Chicago; for more information, see: http://www.crsp.com/.
} 
average stock prices. $^{22}$

We gathered data on CCX membership from the exchange’s website. In 2010, total of 109 entities were members of the CCX exchange, of which 55 were firms that are listed on a US stock market (NASDAQ, NYSE or AMEX). ${ }^{23}$ The majority of the nonlisted entities were cities, states and universities. To find the specific dates when firms announced their decision to join, we used financial news outlets such as Reuters, LexusNexus, environmental news wires, general web searches, as well as companies’ own news releases. We were able to identify an announcement date to join CCX for 34 of the listed firms.

Table 1 contains descriptive statistics of our sample. The sample size for the market variables reflects the number of monthly prices in our sample period.

Table 1 about here.

\section{Results}

Table 2 contains our regression results. All estimates are based on a random effects (RE) specification and robust standard errors, clustered by firm. To test whether different industries have different intercepts (i.e. different $\alpha$ 's), we ran fixed effects (FE) regressions based on 2-digit SIC codes for all samples but were not able to reject the null

\footnotetext{
${ }^{22}$ We use the effective federal funds rate as the risk-free rate of interest. The effective federal funds rate is a weighted average of rates on brokered trades. Monthly figures include each calendar day in the month, and are annualized using a 360-day year or bank interest. Information and data are available at http://www.federalreserve.gov/econresdata/releases/statisticsdata.htm.

${ }^{23}$ The CCX was comprised of a mix of municipalities, non-profits, and for-profit corporations. Among the for-profit firms (the object of this study), over 14 major (SIC) industry groups were represented, including agricultural, manufacturing, financial services, and consumer products. The most frequent industry represented in our sample was energy utilities $(n=17)$, followed by pulp/paper \& packaging $(n=8)$, and petrochemicals $(n=7)$.
} 
hypothesis that the industry intercepts were all identical (results not shown but available on request). The FE regressions also allowed us carry out Hausman tests to confirm the assumption necessary for the RE structure that the individual errors $\mathrm{u}_{\mathrm{i}}$ are uncorrelated with the regressors.

Column A contains the results from estimating the 4-factor model in eq. (3) for the full sample. All coefficients are highly significant and have the expected sign, confirming the validity of the 4 -factor model as a basis for our regressions. In column B we introduce carbon price information, the Waxman dummy, the announcement dummy, as well as the interaction terms in eq. (4). The results indicate that firms' announcements to join CCX was associated with positive excess returns, and that CCX members experienced positive excess returns upon the passing of the Waxman-Markey bill, relative to nonmembers. Both results are consistent with the hypothesis that it pays to engage in voluntary environmental action. On the other hand, member firms' excess returns are not related to carbon prices, at least not differently than excess returns from nonmembers. The positive and statistically significant coefficient on carbon price returns for all firms is presumably due to a correlation between carbon prices and the overall stock market. The four-factor model, as well as the extended version in column B, accounts for about $7 \%$ of the variation in excess returns.

If membership in the treatment group is endogenous, the difference-in-difference estimator can be biased. To address the endogeneity of firms' decision to join the voluntary CCX program, we construct nonmember control groups by means of propensity score matching (see section 3.4) and estimate regressions based on these subsamples. We posit that excess returns in these specifications are less likely to be 
affected by unobserved heterogeneity associated with firm profitability, and thus give more credence to the variables of interest. Using subsamples also allows us to control for unobserved heterogeneity on the industry level by including average excess returns on the 4-digit SIC level. ${ }^{24}$ The coefficient estimates from regressing eq. (4) on the matched samples are shown in columns C-F. As before, we control for firm-level unobserved heterogeneity by including random effects.

Qualitatively, the results are similar to those based on the full sample: There is evidence for positive excess returns after joining CCX (or rather, after announcing to join), as well as for being a CCX member when the Waxman-Markey bill was passed. Whereas the latter is robust to the choice of matching procedure, the significance of the announcement dummy depends on the matching type. It is significant for the matched samples within-industry (D and F), but not across (C and E). The fact that the intercept in models $\mathrm{D}$ and $\mathrm{F}$ is statistically indistinguishable from zero as predicted by economic theory could be interpreted such that these models do a better job in explaining firm excess returns than the across-industry regressions. Note also that the explanatory power of the model has increased dramatically with the inclusion of industry-level excess returns, to $23-26 \%$.

The magnitude of announcement coefficient in models $\mathrm{D}$ and $\mathrm{F}$ is similar in magnitude to the full sample regression, implying monthly excess returns that are about two percentage points higher than those of nonmember firms. Interestingly, the coefficient on the (interacted) Waxman dummy is larger than for the full sample in three

\footnotetext{
24 We do not include excess returns on the industry level for the full sample regressions because this would amount to including a time average of the LHS variable as a regressor, which would then "explain" almost the entire variation of excess returns. This is not the case for the matched-sample regressions because the industry averages are computed using the full sample.
} 
of the four matched regressions, and it is also larger than the announcement effect. The results indicate that member firms experienced excess returns that were five percentage points higher than their nonmember rivals, which is quite large given that average monthly excess returns are about one percent (see Table 1). Note that these are differential excess returns (excess returns for members minus excess returns for controls), meaning that they cannot be due to an exogenous shock that happened to coincide with the Waxman-Markey bill, and which affected all firms. This result implies that preparing for regulation and thus gaining an advantage over rivals who have no carbon market experience may be an important reason to join CCX.

The price of carbon, interacted with membership status or by itself, is not associated with excess returns. This suggests that abatement costs do not affect the share price of CCX member firms, or alternatively, that the CFI price is not a good proxy for abatement costs. ${ }^{25}$ We would expect those firms with higher abatement costs (heavy industry and manufacturing) to experience a negative impact on returns due to CCX membership. However, controlling for emission intensity using 2-digit SIC coding (defining codes 10-14, 26, 28-29, 32-34 and 49 as emission-intensive industry groups) did not reveal a difference between emission-intensive and other firms in terms of the announcement effect and the sensitivity of returns to the carbon price.

\section{Conclusions}

\footnotetext{
25 This point was made by a reviewer. It implies that the CFI market is not efficient in the sense that the CFI price is not equal to marginal abatement costs. Although not consistent with theory, this is a valid point in practice, especially considering the low carbon price and the different impact that reducing emissions and buying offsets may have on consumers and investors. Whereas reducing emissions sends a message of "greenness", buying offsets (which is physically equivalent, conditional on additionality of the offset project) may be perceived less favorably.
} 
The effect of voluntary environmental action on firm profits is ambiguous ex ante. Theoretically, either an increase or decrease in profitability is possible, rendering the question an empirical one. We use monthly stock returns from 1991-2009 to measure the effect on excess returns of firm participation in the CCX, one of the first and largest voluntary cap-and-trade market to date. We control for market risk as well as shocks on the 4-digit industry level and estimate the effect of CCX membership by means of a difference-in-difference approach. We control for self-selection bias by creating a sample of control firms using propensity score matching.

We find some evidence for the hypothesis that the market rewards voluntary climate action: The announcement to join the program was associated with positive excess returns, and in two of our four matching specifications this effect was statistically significant at $\mathrm{p}<0.1$. Furthermore, passing of the Waxman-Markey bill in the US House of Represtantives in 2009, which presumably increased the likelihood of a mandatory regulation on the federal level, was associated with positive and highly significant excess returns for CCX members, implying that the market viewed previous experience in carbon markets as an advantage.

Our results indicate a market reward for potentially useful business experience in the face of uncertainty about environmental regulation. This may not only explain the positive excess returns from the passing of Waxman-Markey, but possibly also the excess returns from joining in the first place: The probability of binding regulation was certainly increased by Waxman-Markey, but it was likely not zero before. Of course, these initial excess returns could also be explained by green preferences or other mechanisms, but the magnitude of the market signal from an increased probability of regulation suggests that 
preparation for future regulation was the dominant factor for joining CCX. It follows that if future regulation were ruled out for some reason, there would not have been an incentive to join CCX either. We conclude that voluntary GHG programs can serve as an experimental hedge by firms facing possible regulation, but that relying on voluntary action alone is not enough to combat climate change. 


\section{References}

Alberini, A. and K. Segerson. Assessing voluntary programs to improve environmental quality. Environmental and Resource Economics, 22(1-2):157 - 184, 2002.

Anton, W. R. Q., G. Deltas and M. Khanna. Incentives for environmental self-regulation and implications for environmental performance. Journal of Environmental Economics and Management, 48(1):632 - 654, 2004.

Arora, S. and S. Gangopadhyay. Toward a theoretical model of voluntary overcompliance. Journal of Economic Behavior and Organization, 28(3):289 - 309, 1995.

Banz, R. W. The relationship between return and market value of common stocks. Journal of Financial Economics, 9(1):3 - 18, 1981.

Barnett, M. L. and R. M. Salomon. Beyond dichotomy: the curvilinear relationship between social responsibility and financial performance. Strategic Management Journal, 27(11):1101 - 1122, 2006.

Carhart, M. M. On persistence in mutual fund performance. Journal of Finance, 52 (1):57 - 82, 1997.

Dasgupta, S., B. Laplante and N. Mamingi. Pollution and capital markets in developing countries. Journal of Environmental Economics and Management, 42(3):310 - 335, 2001.

De Bondt, W. F. M. and R. Thaler. Does the stock market overreact?. Journal of Finance, 40(3):793 - 805, 1985.

Derwall, J., N. Guenster, R. Bauer and K. Koedijk. The eco-efficiency premium puzzle. Financial Analysts Journal, 61(2):51 - 63, 2005.

Dowell, G., S. Hart and B. Yeung. Do corporate global environmental standards create or destroy market value?. Management Science, 46(8):1059, 2000.

Fama, E. F. and K. R. French. The cross-section of expected stock returns. Journal of Finance, 47(2):427 - 465, 1992.

Fama, E. F. and K. R. French. Common risk factors in the returns on stock and bonds. Journal of Financial Economics, 33(1):3 - 56, 1993.

Fama, E. F. and K. R. French. The capital asset pricing model: Theory and evidence. Journal of Economic Perspectives, 18(3):25 - 46, 2004.

Filbeck, G. and R. F. Gorman. The relationship between the environmental and financial performance of public utilities. Environmental and Resource Economics, 29 (2):137 - 157, 2004.

Fisher-Vanden, K. and K. S. Thorburn. Voluntary corporate environmental initiatives and shareholder wealth. Tuck School of Business at Dartmouth Working Paper, December 1998.

Friedman, M. The social responsibility of business is to increase profits. New York Times Magazine, September 131970.

Gupta, S. and B. Goldar. Do stock markets penalize environment-unfriendly behaviour? evidence from India. Ecological Economics, 52(1):81 - 95,2005.

Hart, O. and J. Tirole. Vertical integration and market foreclosure. Brookings Papers on Economic Activity, 205 - 276, 1990.

Hart, S. L. and G. Ahuja. Does it pay to be green? An empirical examination of the relationship 
between emission reduction and firm performance. Business Strategy and the Environment, 5:30-37, 1996.

Heal, G. Corporate social responsibility: An economic and financial framework. Geneva Papers on Risk and Insurance: Issues and Practice, 30(3):387 - 409, 2005.

Heinkel, R., A. Kraus and J. Zechner. The effect of green investment on corporate behavior. Journal of Financial and Quantitative Analysis, 36(4):431 - 449, 2001.

Hintermann, B. Allowance price drivers in the first phase of the eu ets. Journal of Environmental Economics \& Management, 59(1):43 - 56, 2010.

Hintermann, B. Market power, permit allocation and efficiency in emission permit markets. Environmental and Resource Economics, 49(3), p. 327-49, 2011.

Hintermann, B. (2012): Pricing emission permits in the absence of abatement. Energy Economics 34(5): 1329-1340.

Khanna, M. Non-mandatory approaches to environmental protection. Journal of Economic Surveys, 15(3):291 - 324, 2001.

Khanna, M., W. R. H. Quimio and D. Bojilova. Toxics release information: A policy tool for environmental protection. Journal of Environmental Economics and Management, 36(3): 243 $-266,1998$.

Kim, E.-H. and T. P. Lyon. Strategic environmental disclosure: Evidence from the DOE's voluntary greenhouse gas registry. Journal of Environmental Economics and Management, 61: 311-326, 2011.

King, A. A. and M. J. Lenox. Exploring the locus of profitable pollution reduction. Management Science, 48(2):289 - 299, 2002.

King, A. A. and M. J. Lenox. Does it Really pay to be green?. Journal of Industrial Ecology, 5(1):105-116, 2001.

Kollmuss, A., H Zink and C Polycarp. Making sense of the voluntary carbon market: A comparison of carbon offset standards. WWF Germany report, 2008.

Konar, S. and M. A. Cohen. Information as regulation: The effect of community right to know laws on toxic emissions. Journal of Environmental Economics \& Management, 32(1):109124, 1997.

Konar S. and M. A. Cohen. Does the market value environmental performance?. Review of Economics \& Statistics, 83(2):281 - 289, 2001.

Krattenmaker, T. G. and S. C. Salop. Competition and cooperation in the market for exclusionary rights. American Economic Review, 76(2):109, 1986.

Lintner, J. The valuation of risk assets and the selection of risky investments in stock portfolios and capital budgets. Review of Economics \& Statistics, 47(1):13, 1965.

Mallory, J. Will pension funds save the world? An analysis of institutional activism as a potential mechanism for carbon emissions reduction. University of Toronto Working Paper, 2009.

McWilliams, A., D. S. Siegel and P. M. Wright. Corporate social responsibility: Strategic implications. Journal of Management Studies, 43(1):1 - 18, 2006.

Matisoff, D. C. Privatizing Climate Change Policy: Is there a Public Benefit? Environmental and Resource Economics, 53: 409-433, 2012. 
Muoghalu, M. I., P. Little and H. D. Robison. Hazardous waste lawsuits, financial disclosure, and investors' interests. Journal of Accounting, Auditing \& Finance, 10(2):383 - 400, 1995.

Nehrt, C. Timing and intensity effects of environmental investments. Strategic Management Journal, 17(7):535 - 547, 1996.

Oberndorfer, U. EU emission allowances and the stock market: Evidence from the electricity industry. Ecological Economics, 68(4):1116 - 1126, 2009.

Porter, M. E. and C. van der Linde. Toward a new conception of the environmentcompetitiveness relationship. Journal of Economic Perspectives, 9(4): 97 - 118, 1995.

Reinhardt, F. L. Bringing the environment down to earth. Harvard Business Review, 36(3):149 157, 1999.

Russo, M. V. and P. A. Fouts. A resource-based perspective on corporate environmental performance and profitability. Academy of Management Journal, 40(3): 534 - 559, 1997.

Salop, S. C. and D. T. Scheffman. Raising rival's cost. American Economic Review, 73(2):267, 1983.

Salop, S. C. and D. T. Scheffman. Cost-raising strategies. Journal of Industrial Economics, 36(1):19 - 34, 1987.

Sharpe, W. F. Capital asset prices: A theory of market equilibrium under conditions of risk. Journal of Finance, 19(3):425 - 442, 1964.

Sijm, J., K. Neuhoff and Y. Chen. CO2 cost pass through and windfall profits in the power sector. Climate Policy, 6:49-72, 2006.

Telle, K. it pays to be green a premature conclusion? Environmental and Resource Economics, 35:195-220, 2006.

Yamashita, M., W. S. Sen and M. C. Roberts. The rewards for environmental conscientiousness in the u.s. capital markets. Journal of Financial and Strategic Decisions, 12(1):73-82, 1999.

Ziegler A., M. Schroeder and K. Rennings. The effect of environmental and social performance on the stock performance of european corporations. Environmental and Resource Economics, 37:661-680, 2007.

Ziegler, A., T. Busch and V. H. Hoffman. Corporate responses to climate change and financial performance: The impact of climate policy. ETH-CER Working Paper Nr. 09/105, February 2009. 
Table 1: Descriptive statistics of the sample

\begin{tabular}{|c|c|c|c|c|c|c|c|c|}
\hline \multirow{3}{*}{$\begin{array}{l}\text { Sample } \\
\mathbf{N} \\
\end{array}$} & \multicolumn{3}{|c|}{ Full } & \multirow{2}{*}{$\begin{array}{c}\text { all SIC } \\
(n=5) \\
36,086\end{array}$} & \multirow{2}{*}{$\begin{array}{c}\begin{array}{c}\text { within } \\
(\mathbf{n}=5)\end{array} \\
33,249 \\
\end{array}$} & \multirow{2}{*}{$\begin{array}{c}\begin{array}{c}\text { all SIC } \\
(\mathbf{n}=\mathbf{1})\end{array} \\
15,870 \\
\end{array}$} & \multirow{2}{*}{$\begin{array}{c}\begin{array}{c}\text { within } \\
(\mathbf{n}=1)\end{array} \\
16,685\end{array}$} & \multirow{2}{*}{$\begin{array}{c}\text { member } \\
9,539\end{array}$} \\
\hline & \multicolumn{2}{|c|}{$1,763,665$} & $1,763,665$ & & & & & \\
\hline & Min. & Max. & & & Mea & (Std) & & \\
\hline $\begin{array}{l}\text { Excess returns } \\
\left(r_{i t}-r_{f t}\right)\end{array}$ & -0.991 & 23.997 & $\begin{array}{l}0.0093 \\
(0.194)\end{array}$ & $\begin{array}{l}0.0096 \\
(0.113)\end{array}$ & $\begin{array}{l}0.0073 \\
(0.115)\end{array}$ & $\begin{array}{l}0.0094 \\
(0.108)\end{array}$ & $\begin{array}{l}0.0077 \\
(0.111)\end{array}$ & $\begin{array}{l}0.0072 \\
(0.108)\end{array}$ \\
\hline $\begin{array}{l}\text { Market excess ret. } \\
\left(r_{m t}-r_{f t}\right)\end{array}$ & -0.185 & 0.110 & $\begin{array}{l}0.0056 \\
(0.044)\end{array}$ & $\begin{array}{l}0.0057 \\
(0.044)\end{array}$ & $\begin{array}{l}0.0058 \\
(0.044)\end{array}$ & $\begin{array}{l}0.0056 \\
(0.044)\end{array}$ & $\begin{array}{l}0.0054 \\
(0.044)\end{array}$ & $\begin{array}{l}0.0050 \\
(0.044)\end{array}$ \\
\hline$S M B_{t}$ & -0.220 & 0.138 & $\begin{array}{l}0.0001 \\
(0.037)\end{array}$ & $\begin{array}{l}0.0004 \\
(0.037)\end{array}$ & $\begin{array}{l}0.0005 \\
(0.036)\end{array}$ & $\begin{array}{l}0.0005 \\
(0.036)\end{array}$ & $\begin{array}{l}0.0005 \\
(0.036)\end{array}$ & $\begin{array}{l}0.0007 \\
(0.036)\end{array}$ \\
\hline$H M L_{t}$ & -0.099 & 0.139 & $\begin{array}{l}0.0048 \\
(0.035)\end{array}$ & $\begin{array}{l}0.0050 \\
(0.034)\end{array}$ & $\begin{array}{l}0.0050 \\
(0.034)\end{array}$ & $\begin{array}{l}0.0050 \\
(0.034)\end{array}$ & $\begin{array}{l}0.0050 \\
(0.034)\end{array}$ & $\begin{array}{l}0.0050 \\
(0.034)\end{array}$ \\
\hline MOMt $_{t}$ & -0.347 & 0.184 & $\begin{array}{l}0.0062 \\
(0.054)\end{array}$ & $\begin{array}{l}0.0063 \\
(0.053)\end{array}$ & $\begin{array}{l}0.0062 \\
(0.053)\end{array}$ & $\begin{array}{l}0.0061 \\
(0.053)\end{array}$ & $\begin{array}{l}0.0059 \\
(0.054)\end{array}$ & $\begin{array}{l}0.0054 \\
(0.055)\end{array}$ \\
\hline $\begin{array}{l}\text { Carbon price ret. } \\
\left(r_{t}^{c}\right)\end{array}$ & -0.537 & 0.914 & $\begin{array}{l}-0.0012 \\
(0.121)\end{array}$ & $\begin{array}{c}-0.00001 \\
(0.116)\end{array}$ & $\begin{array}{c}0.00002 \\
(0.117)\end{array}$ & $\begin{array}{c}-0.00001 \\
(0.120)\end{array}$ & $\begin{array}{c}-0.00013 \\
(0.123)\end{array}$ & $\begin{array}{r}0.00017 \\
(0.132)\end{array}$ \\
\hline Waxman $\left(\Delta W_{t}\right)$ & -1 & 1 & $\begin{array}{c}0.00002 \\
(0.006)\end{array}$ & $\begin{array}{l}0.0011 \\
(0.038)\end{array}$ & $\begin{array}{l}0.0011 \\
(0.039)\end{array}$ & $\begin{array}{l}0.0025 \\
(0.057)\end{array}$ & $\begin{array}{l}0.0023 \\
(0.055)\end{array}$ & $\begin{array}{l}0.0045 \\
(0.077)\end{array}$ \\
\hline $\begin{array}{l}\text { Industry rival exret } \\
\left(r_{t}^{S I}{ }_{-}-r_{f t}\right)\end{array}$ & -0.942 & 9.497 & $\begin{array}{l}0.0095 \\
(0.096)\end{array}$ & $\begin{array}{l}0.0101 \\
(0.077)\end{array}$ & $\begin{array}{l}0.0085 \\
(0.080)\end{array}$ & $\begin{array}{l}0.0094 \\
(0.079)\end{array}$ & $\begin{array}{l}0.0089 \\
(0.085)\end{array}$ & $\begin{array}{l}0.0083 \\
(0.086)\end{array}$ \\
\hline
\end{tabular}




\section{Table 2: Regressions on Full and Matched Samples}

Dependent Variable: Excess Returns $\left(\mathrm{r}_{\mathrm{it}}-\mathrm{r}_{\mathrm{ft}}\right)$

\begin{tabular}{|c|c|c|c|c|c|c|}
\hline Sample & Full & Full & $\begin{array}{c}\text { all SIC } \\
(n=5)\end{array}$ & $\begin{array}{c}\text { within } \\
(n=5)\end{array}$ & $\begin{array}{c}\text { all SIC } \\
(n=1)\end{array}$ & $\begin{array}{l}\text { within } \\
(n=1)\end{array}$ \\
\hline $\mathbf{N}$ & $1,704,437$ & $1,704,437$ & 35,479 & 32,704 & 15,553 & 16,364 \\
\hline & (A) & (B) & (C) & (D) & $(E)$ & (F) \\
\hline $\begin{array}{l}\text { Market excess returns } \\
\left(r_{m t}-r_{f t}\right)\end{array}$ & $\begin{array}{c}0.974 * * * \\
(163.46)\end{array}$ & $\begin{array}{l}0.972 * * * \\
(162.62)\end{array}$ & $\begin{array}{l}0.360 * * * \\
(5.52)\end{array}$ & $\begin{array}{l}0.346^{* * *} \\
(5.60)\end{array}$ & $\begin{array}{l}0.539 * * * \\
(4.99)\end{array}$ & $\begin{array}{c}0.572^{* * *} \\
\quad(6.91)\end{array}$ \\
\hline$S M B_{t}$ & $\begin{array}{c}0.544 * * * \\
(92.59)\end{array}$ & $\begin{array}{c}0.542 * * * \\
(92.08)\end{array}$ & $\begin{array}{c}-0.0259 \\
(-0.74)\end{array}$ & $\begin{array}{c}0.0188 \\
(0.57)\end{array}$ & $\begin{array}{c}0.0243 \\
(0.49)\end{array}$ & $\begin{array}{c}0.0408 \\
(0.87)\end{array}$ \\
\hline$H M L_{t}$ & $\begin{array}{c}0.201^{* * *} \\
(25.18)\end{array}$ & $\begin{array}{c}0.202^{* * *} \\
(25.30)\end{array}$ & $\begin{array}{l}0.156^{* * * *} \\
\quad(3.82)\end{array}$ & $\begin{array}{l}0.165^{* * *} \\
\quad(3.96)\end{array}$ & $\begin{array}{c}0.279 * * * \\
(4.57)\end{array}$ & $\begin{array}{c}0.223^{* * *} \\
\quad(3.91)\end{array}$ \\
\hline MOMt $_{t}$ & $\begin{array}{c}-0.120 * * * \\
(-27.63)\end{array}$ & $\begin{array}{c}-0.124 * * * \\
(-28.27)\end{array}$ & $\begin{array}{c}-0.0657 * * * \\
(-3.80)\end{array}$ & $\begin{array}{c}-0.0735^{* * *} \\
(-3.88)\end{array}$ & $\begin{array}{c}-0.0957 * * * \\
(-3.41)\end{array}$ & $\begin{array}{c}-0.123 * * * \\
(-4.27)\end{array}$ \\
\hline Carbon returns $\left(r_{t}^{C}\right)$ & & $\begin{array}{c}0.00967 * * * \\
(9.63)\end{array}$ & $\begin{array}{c}-0.000738 \\
(-0.14)\end{array}$ & $\begin{array}{l}0.000630 \\
(0.11)\end{array}$ & $\begin{array}{c}0.00327 \\
(0.44)\end{array}$ & $\begin{array}{c}0.00786 \\
(1.07)\end{array}$ \\
\hline $\begin{array}{l}\text { Carbon ret. } \cdot \text { member } \\
\left(r_{t}^{C} \cdot M_{t-1}+\ln \left(P_{t}^{C}\right) \cdot \Delta M_{t}\right)\end{array}$ & & $\begin{array}{c}-0.0174 \\
(-1.28)\end{array}$ & $\begin{array}{l}0.000943 \\
(0.07)\end{array}$ & $\begin{array}{c}-0.000565 \\
(-0.04)\end{array}$ & $\begin{array}{c}-0.00110 \\
(-0.08)\end{array}$ & $\begin{array}{c}-0.00542 \\
(-0.37)\end{array}$ \\
\hline Announcement $\left(\Delta M_{t}\right)$ & & $\begin{array}{l}0.0226^{* *} \\
(2.13)\end{array}$ & $\begin{array}{c}0.0123 \\
(1.17)\end{array}$ & $\begin{array}{c}0.0181^{*} \\
(1.69)\end{array}$ & $\begin{array}{l}0.0137 \\
(1.30)\end{array}$ & $\begin{array}{c}0.0201 * \\
(1.93)\end{array}$ \\
\hline $\begin{array}{l}\text { Industry ex. returns } \\
\left(r_{t}^{S I C}-r_{f t}\right)\end{array}$ & & & $\begin{array}{l}0.587 * * * \\
(8.47)\end{array}$ & $\begin{array}{l}0.615^{* * * *} \\
(9.00)\end{array}$ & $\begin{array}{c}0.441^{* * *} \\
\quad(3.98)\end{array}$ & $\begin{array}{l}0.421^{* * *} \\
\quad(5.18)\end{array}$ \\
\hline Waxman $\left(\Delta W_{t}\right)$ & & $\begin{array}{l}0.0219 * * * \\
(9.15)\end{array}$ & $\begin{array}{c}-0.0257^{* *} \\
(-2.49)\end{array}$ & $\begin{array}{c}-0.00863 \\
(-0.74)\end{array}$ & $\begin{array}{l}-0.0153 \\
(-1.09)\end{array}$ & $\begin{array}{c}-0.0141 \\
(-1.41)\end{array}$ \\
\hline $\begin{array}{l}\text { Waxman } \cdot \text { member } \\
\left(\Delta W_{t} \cdot M_{t-1}\right)\end{array}$ & & $\begin{array}{l}0.0320^{* *} \\
(2.48)\end{array}$ & $\begin{array}{l}0.0564 * * * \\
(2.91)\end{array}$ & $\begin{array}{c}0.0370 * \\
(1.78)\end{array}$ & $\begin{array}{c}0.0578 * * * \\
(2.76)\end{array}$ & $\begin{array}{l}0.0572 * * * \\
\quad(3.09)\end{array}$ \\
\hline Constant & $\begin{array}{c}0.000904^{* * *} \\
(4.32)\end{array}$ & $\begin{array}{c}0.000872^{* * *} \\
(4.17)\end{array}$ & $\begin{array}{c}0.00124^{* *} \\
(2.34)\end{array}$ & $\begin{array}{c}-0.00119 \\
(-0.66)\end{array}$ & $\begin{array}{l}0.00136 * \\
(1.71)\end{array}$ & $\begin{array}{c}- \\
0.0000856 \\
(-0.09)\end{array}$ \\
\hline R sq. within & 0.0681 & 0.0682 & 0.2354 & 0.2649 & 0.2295 & 0.2405 \\
\hline between & 0.0625 & 0.0629 & 0.1908 & 0.1813 & 0.2615 & 0.1804 \\
\hline overall & 0.0678 & 0.0679 & 0.2356 & 0.2637 & 0.2298 & 0.2403 \\
\hline
\end{tabular}

Notes: t-statistics in parentheses; significance levels: ${ }^{*} \mathrm{p}<0.10 * * \mathrm{p}<0.05 * * * \mathrm{p}<0.01$; use of robust standard errors, clustered by firm. $\mathrm{M}_{\mathrm{t}}$ : Membership dummy $\left(\mathrm{M}_{\mathrm{t}}=1\right.$ if firms have announced to join, $\mathrm{M}_{\mathrm{t}}=0$ otherwise); $\mathrm{Wt}$ : Time dummy ( $\mathrm{W}_{\mathrm{t}}=1$ after Waxman-Markey bill was passed, $\mathrm{W}_{\mathrm{t}}=0$ before). 
Figure 1: CCX carbon price and trading volume, 2003-2010

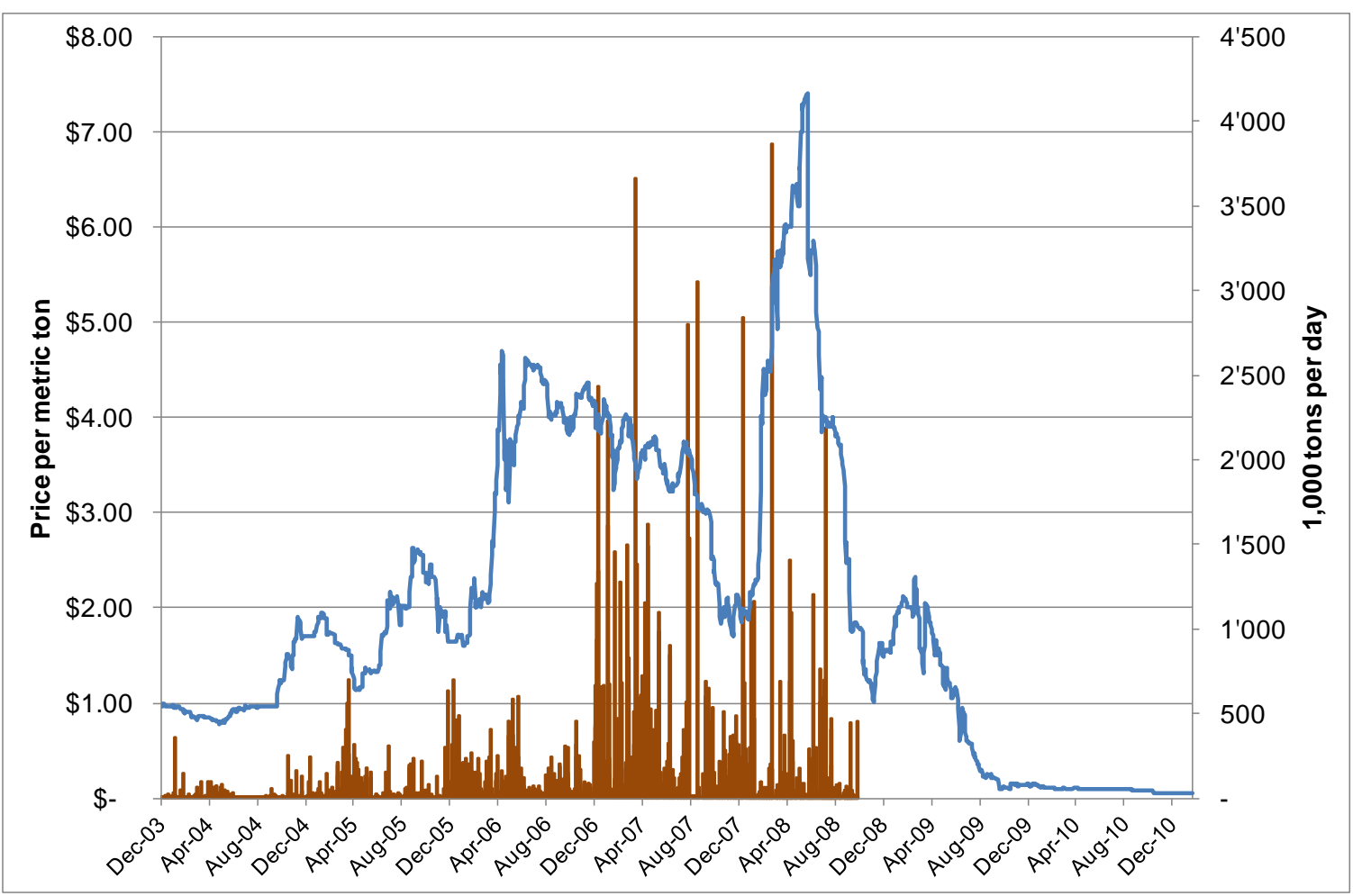

Source: Intercontinental Exchange (ICE) 


\section{Appendix: Derivation of the regression specification}

In order to derive a theoretically consistent regression specification, we start by considering the price equation that gives rise to the CAPM while suppressing the subscripts on the coefficients:

$$
\frac{P_{i t}}{P_{f t}}=e^{\alpha t} \cdot\left(\frac{P_{m t}}{P_{f t}}\right)^{\beta}
$$

or, equivalently,

$$
P_{i t}=e^{\alpha t} \cdot P_{m t}^{\beta} \cdot P_{f t}^{-(\beta-1)}
$$

Taking logs and differentiating w.r.t time gives

$$
\frac{\dot{P_{i t}}}{P_{i t}}=\alpha+\beta \cdot \frac{\dot{P_{m t}}}{P_{m t}}-(\beta-1) \cdot \frac{\dot{P_{f t}}}{P_{f t}}
$$

where a dot represents a time derivative. Rearranging and discretizing in order to accommodate market data results in

$$
\frac{\Delta P_{i t}}{P_{i t-1}}-\frac{\Delta P_{f t}}{P_{f t-1}}=\alpha+\beta \cdot\left(\frac{\Delta P_{m t}}{P_{m t-1}}-\frac{\Delta P_{f t}}{P_{f t-1}}\right)
$$

where $\Delta$ is the first-difference operator. Since proportional first differences are equal to returns, (A4) is equivalent to eq. (2) in the main text. We now add average prices for “small” and "big” (in terms of market value), "high” and "low” (in terms of book-tomarket ratio) and “winners” and “losers” (in terms of the past month’s market performance), which are the basis for the SMB, HML and MOM factors. This leads to the following equation in prices:

$$
P_{i t}=P_{f t} \cdot e^{\alpha t} \cdot\left(\frac{P_{m t}}{P_{f t}}\right)^{\beta_{1}} \cdot\left(\frac{P_{t}^{\text {small }}}{P_{t}^{\text {big }}}\right)^{\beta_{2}} \cdot\left(\frac{P_{t}^{\text {high }}}{P_{t}^{\text {low }}}\right)^{\beta_{3}} \cdot\left(\frac{P_{t}^{\text {growth }}}{P_{t}^{\text {blue }}}\right)^{\beta_{4}} \equiv \Gamma_{t}
$$


Following the same steps as above and using the definitions of the four factors, this becomes eq. (3) defined in returns.

The RHS of (A5) does not include any firm-specific information but only depends on aggregate market data. We now introduce firm-specific information. Specifically, we include industry-level stock prices $P_{i t}^{s i c}$, the CCX carbon price $P_{t}^{C}$, and dummies indicating CCX membership $M_{i t}$ (1 for CCX members, 0 otherwise) and the passing of the Waxman-Markey bill $W_{t}$ (1 for June 2009, 0 otherwise). Since the effect of the carbon price and Waxman-Markey can be expected to differ between members and nonmembers, we also include interaction terms. In order to be consistent (both in terms of theory and math) with the four-factor model, we add these terms multiplicatively to the price equation:

$$
P_{i t}=\Gamma_{t} \cdot e^{\gamma_{1} M_{i t}} \cdot e^{\gamma_{2} W_{t}} \cdot e^{\gamma_{3} M_{i t} W_{t}} \cdot\left(\frac{P_{i t}^{s i c}}{P_{f t}}\right)^{\delta_{1}} \cdot\left(P_{t}^{C}\right)^{\delta_{2}} \cdot\left(P_{t}^{C}\right)^{\left(\delta_{3} M_{i t}\right)}
$$

Taking logs and differentiating w.r.t time:

$$
\begin{aligned}
\frac{\dot{P_{i t}}}{P_{i t}}=\frac{\dot{\Gamma_{t}}}{\Gamma_{t}} & +\gamma_{1} \dot{M}_{i t}+\gamma_{2} \dot{W}_{t}+\gamma_{3}\left(\dot{M}_{i t} W_{t}+M_{i t} \dot{W}_{t}\right) \\
& +\delta_{1}\left(\frac{\dot{P_{i t}^{s i c}}}{P_{i t}^{s i c}}-\frac{\dot{P_{f t}}}{P_{f t}}\right)+\delta_{2} \frac{\dot{P_{t}^{C}}}{P_{t}^{C}}+\delta_{3}\left(M_{i t} \frac{\dot{P_{t}^{C}}}{P_{t}^{C}}+\dot{M}_{i t} \ln \left(P_{t}^{C}\right)\right)
\end{aligned}
$$

Substituting for $\Gamma_{t}$, discretizing and using the fact that all member firms joined CCX before June 2009 (implying that $\Delta M_{i t} W_{t-1}=0 \forall t$ ) leads to the following specification: 


$$
\begin{aligned}
\frac{\Delta P_{i t}}{P_{i t-1}}-\frac{\Delta P_{f t}}{P_{f t-1}}= & \alpha+\beta_{1}\left(\frac{\Delta P_{m t}}{P_{m t-1}}-\frac{\Delta P_{f t}}{P_{f t-1}}\right)+\beta_{2}\left(\frac{\Delta P_{t}^{\text {small }}}{P_{t-1}^{\text {small }}}-\frac{\Delta P_{t}^{\text {big }}}{P_{t-1}^{\text {big }}}\right) \\
& +\beta_{3}\left(\frac{\Delta P_{t}^{\text {high }}}{P_{t-1}^{\text {high }}}-\frac{\Delta P_{t}^{\text {low }}}{P_{t-1}^{\text {low }}}\right)+\beta_{4}\left(\frac{\Delta P_{t}^{\text {growth }}}{P_{t-1}^{\text {growth }}}-\frac{\Delta P_{t}^{\text {blue }}}{P_{t-1}^{\text {blue }}}\right) \\
& +\gamma_{1} \Delta M_{i t}+\gamma_{2} \Delta W_{t}+\gamma_{3} M_{i t-1} \Delta W_{t} \\
& +\delta_{1}\left(\frac{\Delta P_{i t}^{\text {sic }}}{P_{i t-1}^{\text {sic }}}-\frac{\Delta P_{f t}}{P_{f t-1}}\right)+\delta_{2} \frac{\Delta P_{t}^{C}}{P_{t-1}^{C}}+\delta_{3}\left(M_{i t-1} \frac{\Delta P_{t}^{C}}{P_{t-1}^{C}}+\Delta M_{i t} \ln \left(P_{t-1}^{C}\right)\right)
\end{aligned}
$$

Writing the proportional first differences as returns and substituting the definitions of the SMB, HML and MOM factors, this becomes eq. (4). 